\title{
In vitro cytotoxic activity of medicinal plants from Nigeria ethnomedicine on Rhabdomyosarcoma cancer cell line and HPLC analysis of active extracts
}

\author{
Omonike O. Ogbole ${ }^{1 *}$, Peter A. Segun ${ }^{2}$ and Adekunle J. Adeniji ${ }^{3}$
}

\begin{abstract}
Background: Cancer is a leading cause of death world-wide, with approximately 17.5 million new cases and 8.7 million cancer related deaths in 2015. The problems of poor selectivity and severe side effects of the available anticancer drugs, have demanded the need for the development of safer and more effective chemotherapeutic agents. The present study was aimed at determining the cytotoxicities of 31 medicinal plants extracts, used in Nigerian ethnomedicine for the treatment of cancer.

Methods: The plant extracts were screened for cytotoxicity, using the brine shrimp lethality assay (BSLA) and MTT cytotoxicity assay. Rhabdomyosarcoma (RD) cell line, normal Vero cell line and the normal prostate (PNT2) cell line were used for the MTT assay, while Artemia salina nauplii was used for the BSLA. The phytochemical composition of the active plant extracts was determined by high performance liquid chromatography (HPLC) analysis.

Results: The extract of Eluesine indica (L.) Gaertn (Poaceae), with a $L C_{50}$ value of $76.3 \mu \mathrm{g} / \mathrm{mL}$, had the highest cytotoxicity on the brine shrimp larvae compared to cyclophosphamide $\left(\mathrm{LC}_{50}=101.3 \mu \mathrm{g} / \mathrm{mL}\right)$. Two plants extracts, Macaranga barteri Mull. Arg. (Euphorbiaceae) and Calliandra portoricensis (Jacq.) Benth (Leguminosae) exhibited significant cytotoxic activity against the RD cell line and had comparable lethal activity on the brine shrimps. Further cytotoxic investigation showed that the dichloromethane fraction of Macaranga barteri (DMB) and the ethyl acetate fraction of Calliandra portoricensis (ECP), exhibited approximately 6-fold and 4-fold activity, respectively, compared to cyclophosphamide on RD cell line. Determination of selective index (SI) using Vero and PNT2 cell line indicated that DMB and ECP displayed a high degree of selectivity against the cancer cell under investigation. HPLC analysis showed that 3,5dicaffeoylquinic acid, acteoside, kampferol-7-O-glucoside and bastadin 11 were the major components of DMB while the major components of ECP were neurolenin B, nigrosporolide and trans-geranic acid.
\end{abstract}

Conclusion: The results demonstrate the cytotoxicity of Macaranga barteri and Calliandra portoricensis extracts, which are used in Nigerian folklore for cancer treatment.

Keywords: Nigeria, Ethnomedicine, Cancer, MTT assay, Brine shrimp lethality assay, Macaranga Barteri, Calliandra portoricensis

\footnotetext{
*Correspondence: nikeoa@yahoo.com

'Department of Pharmacognosy, Faculty of Pharmacy, University of Ibadan,

Ibadan, Nigeria

Full list of author information is available at the end of the article
}

(c) The Author(s). 2017 Open Access This article is distributed under the terms of the Creative Commons Attribution 4.0 International License (http://creativecommons.org/licenses/by/4.0/), which permits unrestricted use, distribution, and reproduction in any medium, provided you give appropriate credit to the original author(s) and the source, provide a link to the Creative Commons license, and indicate if changes were made. The Creative Commons Public Domain Dedication waiver (http://creativecommons.org/publicdomain/zero/1.0/) applies to the data made available in this article, unless otherwise stated. 


\section{Background}

Cancer remains a leading cause of death worldwide, with approximately 17.5 million new cases and 8.7 million cancer related deaths in 2015 [1]. With approximately $20 \%$ of the population of Africa and slightly more than half the population of West Africa, Nigeria contributed $11 \%$ to the estimated 681,000 new cases of cancer that occurred in Africa in 2008 [2]. In Nigeria, the common cancer types include cancer of the breast, cervix, prostate, colorectal, liver cancer and Non Hodgkin Lymphoma [3]. Rhabdomyosarcoma (RD) is the commonest soft tissue sarcoma in children and adolescents below 20 years. In the US, the incidence of RD is approximately five cases per million children/adolescents per year, and, in $>50 \%$ of cases, RD occurs during the first decade of life [4]. In Nigeria, rhabdomyosarcoma occurs frequently in the paediatric population, and it is a common cause of mortality in this age group. The most prevalent variant is the embryonal rhabdomyosarcoma and the commonest anatomical sites are the head and neck regions [5]. Several chemotherapeutic agents are being used for the management of cancer but the problem of selective toxicity and severe side effects still exist. Hence, there is an urgent need to discover new anticancer drug leads.

Natural products have been used since ancient times for the treatment of many diseases. Before the 20th century, $80 \%$ of all medicines used to treat human and animal illness were obtained from the leaves, barks and roots of medicinal plants. During that period, crude botanicals were percolated in readily available fluids like alcohol and the doctor will prescribe tablespoons of the fluid extract to be taken for a period. It is noteworthy to mention that about $70 \%$ of the drugs used today are models of natural products [6]. Between 1981 and 2010, approximately 700 natural products or natural product derived New Chemical Entities (NCEs) were approved [7]. Biodiversity and traditional medical knowledge had provided useful lead compounds for cancer chemotherapy, as exemplified in the discovery of the vinca alkaloids (vincristine and vinblastine), taxols (paclitaxel and docetaxel), camptothecin and etoposide [8, 9].

According to the World Health Organization (WHO), $80 \%$ of people living in developing nations, which includes Nigeria, depend on herbal medicine to meet their health care needs [10]. Nigeria is a country blessed with a vast flora of medicinal importance and the therapeutic potency of such plants have been demonstrated by several researchers $[11,12]$. In Nigeria, many people especially those residing in the rural areas, solely depend on the traditional medical practitioners (TMPs) for the diagnosis and treatment of many diseases including cancer. Interestingly, several studies have documented the indigenous knowledge of the TMPs in the treatment of various cancers across the geopolitical zones of Nigeria
[13-15]. Although, the cytotoxicity of some of these plants have been investigated $[16,17]$, there is yet to be a plant from Nigerian ethnomedicine that have produced a lead in anticancer drug discovery.

In this framework, data on plants used in the treatment of cancer by the TMPs in the Ijebu region of southwestern Nigeria were collected, by personal contact with the TMPs during an ethnobotanical survey conducted between May September 2015. From the 90 plants that were recorded during the survey, bibliographical survey permitted to retain 31 indigenous plants for which cytotoxic activity had never been evaluated or only partially studied. The present study investigates the in vitro cytotoxicity of the methanol extract of the medicinal plants and the active fractions against Artemia salina nauplii and RD, Vero and PNT2 cell line.

\section{Methods}

\section{Plant material}

The selected plants were collected between September 2015 and May 2016 in their natural habitat (Table 1). The plants were identified and authenticated by comparison with appropriate voucher specimens at Department of Pharmacognosy, Herbarium, University of Ibadan (DPHUI) by Mr. P. Agwu and the Forest Herbarium Ibadan, Forestry Research Institute of Nigeria (FRIN), by Mr. T.K. Odewo.

\section{Preparation of crude extracts and fractions}

Plant parts were air-dried at room temperature and milled into coarse powder. For each plant material, $300 \mathrm{~g}$ of material was macerated in methanol, with intermittent stirring, for $72 \mathrm{~h}$ at room temperature. The extracts were filtered and concentrated to dryness using a rotary evaporator. Dry extracts were stored at $4{ }^{\circ} \mathrm{C}$ until analysis. To obtain fractions of different polarity from the active extracts, $20 \mathrm{~g}$ of the crude extracts (M. barteri and $C$. portoricensis) were re-dissolved in $250 \mathrm{~mL}$ of distilled water and partitioned $(3 \times)$ with an equal volume of $n$-hexane, dichloromethane and ethyl acetate. Fractions were concentrated under reduced pressure.

\section{Brine shrimp lethality assay (BSLA)}

The BSLA assay is a bench top assay used for screening natural products for the presence of bioactive compounds. The experiment was carried out using the method described by Mclaughlin [18]. Brine shrimp eggs were obtained from the Department of Pharmacognosy, University of Ibadan. Briefly, Artemia salina cysts (brine shrimp eggs $0.1 \mathrm{~g}$ ) were allowed to hatch in natural sea water, containing $3.8 \mathrm{~g} / \mathrm{L}$ salt, obtained from Bar beach, Ikoyi, Lagos. The larvae (nauplii) were placed in sea water for $48 \mathrm{~h}$ at $25^{\circ} \mathrm{C}$ under constant aeration and illumination to ensure survival and maturity before use. Stock solutions $(10 \mathrm{mg} / \mathrm{mL})$ of plant extracts were made and diluted serially in clean test tubes of $10 \mathrm{~mL}$ volume to obtain five final 
Table 1 Plant species analysed for cytotoxicity

\begin{tabular}{|c|c|c|c|c|c|}
\hline $\mathrm{S} / \mathrm{N}$ & Plant & Family & Local name & Part used & Voucher numbe \\
\hline 1 & Acanthospermum hispidum D.C. & Asteraceae & Dagunro gogoro & Aerial part & FHI 110050 \\
\hline 2 & Alchornea laxiflora (Benth.) Pax \& K.Hoffm. & Euphorbiaceae & Pepe & leaf & FHI 110155 \\
\hline 3 & Boerhavia diffusa $\mathrm{L}$. & Nyctaginaceae & Etipase-erinla & Root & FHI 109603 \\
\hline 4 & Calliandra portoricensis (Jacq.) Benth & Leguminosae & Tude & Root & FHI 109672 \\
\hline 5 & Clausena anisata (Willd.) Hook.f. ex Benth. & Rutaceae & Atabari obuko & Leaves & FHI 99457 \\
\hline 6 & Croton gratissimus Burch. & Euphorbiaceae & Ajekobale & Leaves & FHI 109041 \\
\hline 7 & Eleusine indica (L.) Gaertn & Poaceae & Gbegi & Whole plant & FHI 92140 \\
\hline 8 & Entandrophragma utile (Dawe \& Sprague) Sprague & Meliaceae & Jebo & Stem bark & FHI 86848 \\
\hline 9 & Ficus sur Forssk. & Moraceae & Opoto & leaves & FHI 109329 \\
\hline 10 & Heliotropium indicum L. & Boraginaceae & Apari igun & Aerial part & FHI 110156 \\
\hline 11 & Holarrhena floribunda & Apocynaceae & Dagba & leaves & FHI 110053 \\
\hline 12 & Hoslundia opposita Vahl & Lamiaceae & Efirin-odan & Leaves & DPHUI 0341 \\
\hline 13 & Ipomoea asarifolia (Desr.) Roem. \& Schult. & Convolvulaceae & Gboro ayaba & leaves & FHI 110052 \\
\hline 14 & Lagenaria breviflora (Benth.) Roberty & Cucurbitaceae & Tagiri & Seed & $\mathrm{FHI} 109040$ \\
\hline 15 & Lecaniodiscus cupanioides Planch. Ex Benth. & Sapindaceae & Arika & leaves & FHI 110081 \\
\hline 16 & Lippia multiflora Moldenke & Verbenaceae & Eforomoba & leaves & DPHUI 0412 \\
\hline 17 & Macaranga barteri Mull. Arg. & Euphorbiaceae & Agbasa & Leaves & FHI 107230 \\
\hline 18 & Mimosa pudica $\mathrm{L}$. & Mimosaseae & Patanmo & Leaves & FHI 100332 \\
\hline 19 & Mondia whitei (Hook.f.) Skeels & Periplocacaea & Isirigun & Leaves & $\mathrm{FHI} 110043$ \\
\hline 20 & Nauclea diderrichii (De Wild.) Merr. & Rubiaceae & Opepe & Stem bark & FHI 110049 \\
\hline 21 & Parquetina nigrescens (Afzel.) Bullock & Apocynaceae & Ogbo & leaves & FHI 110044 \\
\hline 22 & Petiveria alliacea L. & Phytolacaceae & Awopa & leaves & DPHUI 0095 \\
\hline 23 & Picralima nitida (Stapf) T. Durand \& H. Durand & Apocynaceae & Abeere & Seed & FHI 108794 \\
\hline 24 & Piper guineensis Schumach. \& Thonn. & Piperaceae & lyere & leaves & FHI 110051 \\
\hline 25 & $\begin{array}{l}\text { Sarcocephalus latifolius (Sm.) } \\
\text { E.A.Bruce }\end{array}$ & Rubiaceae & Egbesi & Leaves & DPHUI 1591 \\
\hline 26 & Secamone afzelii (roem et Schult) K. Schum & Asclepiadaceae & Ailu & Leaves & FHI 109995 \\
\hline 27 & Spondias mombin L. & Anacardiaceae & lyeye & Leaves, & FHI 63948 \\
\hline 28 & Terminalia ivorensis (A. Chev.) & Combretaceae & Afara-dudu & Stem bark & FHI 105432 \\
\hline 29 & Terminalia superba (Engl. \& Diels.) & Combretaceae & Afara & Stem bark & DPHUI 0214 \\
\hline 30 & Tetracera alnifolia Willd. & Dilieniaceae & Opon & Leaves & FHI 107511 \\
\hline 31 & Trichilia monadelpha Benth. & Meliaceae & & leaves & FHI 108844 \\
\hline
\end{tabular}

concentrations $(1000-1 \mu \mathrm{g} / \mathrm{mL})$. Ten nauplii were collected with the aid of a pipette and added to the serially diluted test solutions. Test were carried out in triplicate. The negative control consisted of ten nauplii per tube in sea water without plant extract while cyclophosphamide was used as the positive control. After the $24 \mathrm{~h}$ incubation at $25^{\circ} \mathrm{C}$, a magnifying lens was used to count the number of dead larvae and the percentage mortality was calculated. Larvae were considered dead only if they did not move for few seconds after pricking with sharp object during observation. The $50 \%$ lethal concentration $\left(\mathrm{LC}_{50}\right.$ value) and the standard error mean (SEM) were calculated using a nonlinear regression curve contained in the Graph pad prism statistical software.
Determination of effect of plant extract on cell proliferation by MTT assay

\section{Cell culture}

Cytotoxic studies were determined in human Rhabdomyosarcoma (RD) cells (CDC, Atlanta, USA), African green monkey kidney (Vero) cell (WHO Reference Polio laboratory, UCH, Ibadan, Nigeria) and the normal human prostate (PNT2) cell line obtained from the (WHO Reference Polio laboratory, UCH, Ibadan, Nigeria). Cells were grown in Eagle's MEM supplemented with $10 \%$ FBS, 100 units $/ \mathrm{mL}$ of penicillin, $100 \mathrm{mg} / \mathrm{mL}$ of streptomycin, $2 \mathrm{mM} \mathrm{L}$-glutamine, $0.07 \% \mathrm{NaHCO}_{3}$, and $1 \%$ non-essential amino acids and vitamin solution. Cultures were maintained in a humidified atmosphere with $5 \% \mathrm{CO}_{2}$ at $37^{\circ} \mathrm{C}$ and passaged bi-weekly. 


\section{Cytotoxicity assay}

Cell viability was examined by the ability of the cells to cleave the tetrazolium salt MTT [3-(4,5-dimethylthiazol2-yl)-2,5- diphenyl tetrazolium bromide (Sigma, Chem, St. Louis, MO), by the mitochondrial enzyme succinate dehydrogenase following the procedure as described earlier [19]. Briefly, each extract was pre-solubilized in dimethylsulphoxide (DMSO) at $37{ }^{\circ} \mathrm{C}$ to give a stock solution (SS) of $1 \mathrm{mg} / \mathrm{mL}$. Serial ten-fold dilutions were made from SS to give working concentrations of $1000-0.01 \mu \mathrm{g} / \mathrm{mL}$, making sure that the final concentration of DMSO in the tested dilutions was not higher than $1 \%$. Confluent monolayers of $\mathrm{RD} /$ Vero cells were grown in 96 well-microtitre plates for $24 \mathrm{~h}$. Cells were incubated with various concentrations of the test extracts in triplicate at $37{ }^{\circ} \mathrm{C}$ in a $\mathrm{CO}_{2}$ environment for $72 \mathrm{~h}$. The negative control was performed using growth medium alone instead of plant extract, while cyclophosphamide (CTX) was used as the positive control. In addition, the cell viability was examined microscopically for the presence or otherwise of cytopathic effect (CPE). At the expiration of the $72 \mathrm{~h}$ treatment period, supernatants were removed from the wells and $25 \mu \mathrm{L}$ of the MTT solution $(2 \mathrm{mg} / \mathrm{mL}$ in PBS) was added to each well. The plates were incubated for $1.5 \mathrm{~h}$ at $37{ }^{\circ} \mathrm{C}$, and $125 \mu \mathrm{L}$ of DMSO was added to each well to dissolve the formazan crystals. The plates were placed on a shaker for $15 \mathrm{~min}$ and the optical density was determined at $492 \mathrm{~nm}$ on a multi-well spectrophotometer (Multiskan, Thermo Fisher Scientific, Waltham, MA). The $50 \%$ cytotoxic concentration $\left(\mathrm{CC}_{50}\right)$ was defined as the extract/compound concentration required for the reduction of cell viability by half. The $\mathrm{CC}_{50}$ value and the standard error mean (SEM) were calculated using a non-linear regression curve contained in the Graph pad prism statistical software.

\section{Selectivity index (SI)}

The normal African green monkey kidney epithelial cell line (Vero) and the normal human prostate (PNT2) cell line were used to measure the SI. The SI of the most active fraction was calculated as the ratio of cytotoxic effect on normal cell line to the cytotoxic effect on cancer (RD) cell line.

\section{High performance liquid chromatography (HPLC) analysis}

The active fractions were subjected to HPLC analysis using the Dionex HPLC System 2695 (Waters). Reversedphase analytical HPLC experiments were performed on a thermoscientific NX $5 \mu \mathrm{M}$ C18 column $(250 \times 4.6 \mathrm{~mm})$. The column temperature was set at $25{ }^{\circ} \mathrm{C}$. A variable wavelength ultraviolet-visible detector was set at $235 \mathrm{~nm}$. $0.1 \%$ trifluoroacetic acid in water (solvent $\mathrm{A}$ ) and $0.1 \%$ trifluoroacetic acid in methanol (solvent B) was used as the eluent. For the analysis, the mobile phase composed of $70 \%$ of $\mathrm{A}$ and $30 \% \mathrm{~B}$ at $0 \mathrm{~min}$, then linear gradient to
$100 \%$ of B over 40 min and held at that composition for $10 \mathrm{~min}$ at a flowrate of $1 \mathrm{~mL} / \mathrm{min}$. To determine that nature of the compounds present in these active fractions, the peaks generated in the chromatogram of each active fraction were compared to the compounds collection contained in the HPLC library.

\section{Results}

\section{Brine shrimp lethality assay}

The result obtained showed that the activity of all the plant extracts were concentration-dependent. All the plant extracts, with the exception of Nauclea diderrichii extract, had $\mathrm{LC}_{50}$ value below $1000 \mu \mathrm{g} / \mathrm{mL}$ indicating the presence of bioactive secondary metabolites in these plants. Eleusine indica extract $\left(\mathrm{LC}_{50}=76.3 \mu \mathrm{g} / \mathrm{mL}\right)$ had the highest cytotoxicity on the brine shrimps compared to cyclophosphamide $\left(\mathrm{LC}_{50}=101.3 \mu \mathrm{g} / \mathrm{mL}\right)$. The result of the BSLA is summarized in Table 2.

\section{MTT assay and selectivity studies}

The result obtained showed that from the selected 31 plants extracts, only eleven had cytotoxicity with $\mathrm{CC}_{50}$ less than $30 \mu \mathrm{g} / \mathrm{mL}$ (Table 2). The methanol crude extract of Macaranga barteri leaves had the highest cytotoxicity on $\mathrm{RD}$ cell line, with a $\mathrm{CC}_{50}$ value of $0.22 \mu \mathrm{g} / \mathrm{mL}$, followed by the methanol crude extract of Calliandra portoricensis root with a $\mathrm{CC}_{50}$ value of $0.82 \mu \mathrm{g} / \mathrm{mL}$, compared to cyclophosphamide $\left(C_{50}\right.$ value $\left.=0.97 \mu \mathrm{g} / \mathrm{mL}\right)$. Other plants with significant cytotoxic effect against the RD cell line include Mimosa pudica, Clausena anisata, Eleusine indica, Secamone afzelii, Lagenaria breviflora, Terminalia ivorensis, Lecaniodiscus cupanioides, Ficus sur and Acanthospermum hispidum (Table 2).

Macaranga barteri and Calliandra portoricensis were selected for further studies based on their cytotoxic activities. The crude methanol extracts of both plants were partitioned into $n$-hexane, dichloromethane and ethyl acetate. The DCM fraction of $M$. barteri (DMB) with a $\mathrm{CC}_{50}$ value of $0.15 \mu \mathrm{g} / \mathrm{mL}$ and the ethyl acetate fraction of C. portoricensis (ECP) with a $\mathrm{CC}_{50}$ value of $0.25 \mu \mathrm{g} / \mathrm{mL}$ showed the highest activity among the fractions. The SI result revealed that DMB had a SI value of 13.7 when compared to CTX with SI of 5.4 while the ECP showed a SI value of 11.1 (Table 3).

\section{HPLC analysis of active extracts}

The HPLC profile of DMB shows 19 distinct peaks, with each peak demonstrating a particular chemical compound. Peak 4, 6, 12 and 16 which represents 3,5-dicaffeoylquinic acid, acteoside, kampferol-7-O-glucoside and bastadin 11, respectively, were the major compounds present, as observed in the chromatogram (Figs. 1 and 2). Figure 2 showed the UV spectra assignment of the major peaks of the DCM fraction. The HPLC analysis of ECP 
Table 2 Brine shrimp lethal activity (BSLA) and in vitro cytotoxicity of methanol extract selected plants on RD cells

\begin{tabular}{|c|c|c|c|}
\hline $\mathrm{S} / \mathrm{N}$ & Plant & $\begin{array}{l}\text { BSLA, } \mathrm{LC}_{50} \\
(\mu \mathrm{g} / \mathrm{mL}, n=3)\end{array}$ & $\begin{array}{l}\text { MTT Assay, } C_{50} \\
(\mu \mathrm{g} / \mathrm{mL}, \mathrm{n}=3)\end{array}$ \\
\hline 1 & Acanthospermum hispidum & $183.70 \pm 5.64$ & $19.65 \pm 1.23$ \\
\hline 2 & Alchornea laxiflora & $142.40 \pm 4.14$ & $>100$ \\
\hline 3 & Boerhavia diffusa & $424.7 \pm 11.64$ & $>100$ \\
\hline 4 & Calliandra portoricensis & $188.5 \pm 5.94$ & $0.82 \pm 0.08$ \\
\hline 5 & Clausena anisata & $318.2 \pm 8.12$ & $8.83 \pm 0.59$ \\
\hline 6 & Croton gratissimus & ND & $>100$ \\
\hline 7 & Eleusine indica & $76.3 \pm 2.61$ & $11.42 \pm 1.01$ \\
\hline 8 & Entandrophragma utile & $247.1 \pm 5.64$ & $51.74 \pm 3.71$ \\
\hline 9 & Ficus sur & ND & $19.23 \pm 3.21$ \\
\hline 10 & Heliotropium indicum & $391.30 \pm 11.24$ & $>100$ \\
\hline 11 & Hoslundia opposite & $149.8 \pm 11.61$ & $>100$ \\
\hline 12 & Holarrhena floribunda & $595.10 \pm 15.11$ & $>100$ \\
\hline 13 & Ipomoea asarifolia & $484 \pm 9.12$ & $88.21 \pm 5.61$ \\
\hline 14 & Lagenaria breviflora & $273.2 \pm 7.98$ & $12.17+0.81$ \\
\hline 15 & Lecaniodiscus cupanioides & ND & $17.23 \pm 1.98$ \\
\hline 16 & Lippia multiflora & ND & $>100$ \\
\hline 17 & Macaranga barteri & $159.13 \pm 11.12$ & $0.22 \pm 0.01$ \\
\hline 18 & Mimosa pudica & $443.2 \pm 7.22$ & $2.03 \pm 0.11$ \\
\hline 19 & Mondia whitei & ND & $>100$ \\
\hline 20 & Nauclea diderrichii & $>1000$ & $>100$ \\
\hline 21 & Parquetina nigrescens & ND & $43.22 \pm 2.43$ \\
\hline 22 & Petiveria alliacea & ND & $>100$ \\
\hline 23 & Picralima nitida & $260.6 \pm 9.64$ & $55.59 \pm 3.01$ \\
\hline 24 & Piper guineensis & $285.50 \pm 1.16$ & $>100$ \\
\hline 25 & Sarcocephalus latifolius & $616.2 \pm 5.63$ & $>100$ \\
\hline 26 & Secamone afzelii & $450.5 \pm 8.61$ & $11.99 \pm 2.01$ \\
\hline 27 & Spondias mombin & ND & $53.33 \pm 5.21$ \\
\hline 28 & Terminalia ivorensis & $492.9 \pm 10.12$ & $13.42 \pm 0.92$ \\
\hline 29 & Terminalia superba & $161.7 \pm 5.35$ & $>100$ \\
\hline 30 & Tetracera alnifolia & $155.1 \pm 1.94$ & $>100$ \\
\hline 31 & Trichilia monadelpha & ND & $>100$ \\
\hline 32 & Cyclophosphamide & $101.3 \pm 1.12$ & $0.97 \pm 0.03$ \\
\hline
\end{tabular}

$n$ no. of replicates, $N D$ Not determined

revealed the presence of neurolenin $\mathrm{B}$, nigrosporolide and 3,5,7-trimethyloctane-2,5-dienedioic as the major compounds, as observed in the chromatogram (Fig. 3). Figure 4 showed UV spectra assignment of major peaks of the EtOAc fraction of ECP.

\section{Discussion}

Thirty-one plant extracts belonging to 25 families were screened using the BSLA. Eleusine indica extract with $\mathrm{LC}_{50}$ value of $76.3 \mu \mathrm{g} / \mathrm{mL}$ had the highest cytotoxicity amongst the plant extracts. Although, BSLA is inadequate in determining the mechanism of action of the bioactive substances in plants nor is it specific for antitumor activity, it provides a preliminary screen that can be supported by a more specific bioassay, once the active compounds have been isolated [20]. Plants found to be toxic to brine shrimp are likely to be good candidate for anti-cancer research [21].

The MTT assay is a sensitive, quantitative and reliable colorimetric assay that measure cell viability. The assay is based on the capacity of the cellular mitochondrial dehydrogenase enzyme in living cells to reduce the yellow water-soluble substrate 3-(4,5-dimethylthiazol2yl)-2,5-diphenyl tetrazolium bromide (MTT) into a dark blue/purple formazan product which is insoluble in water. The amount of formazan produced is directly proportional to the cell number in a range of cells lines $[22,23]$. According to the American National Cancer Institute (NCI), the criteria of cytotoxicity for crude extracts is an $\mathrm{CC}_{50}<30 \mu \mathrm{g} / \mathrm{mL}$ after an exposure time of $72 \mathrm{~h}$ in a preliminary assay [24]. Eleven of the plant extracts met this criteria with $\mathrm{CC}_{50}$ value less than $30 \mu \mathrm{g} / \mathrm{mL}$ (Table 2), with the crude methanol extract of Macaranga barteri and Calliandra portoricensis being the most cytotoxic. Incidentally, the methanol extract of $M$. barteri and C. portoricensis also had significant toxicity against brine shrimp nauplii. Bioactivity-guided fractionation revealed that the cytotoxic constituents of $M$. barteri lies in the dichloromethane fraction (DMB) while that of $C$. portoricensis is contained in the ethyl acetate fraction (ECP).

The primary goal of cancer chemotherapy is to specifically target cancer cells without displaying toxicity towards normal cells. This is the limitation to the use of several chemotherapeutic agents, hence, selective toxicity must be put in consideration in the discovery of leads for cancer treatment [25]. To determine whether the fractions will be cytotoxic to cancer cell lines with very minimal toxicity to normal cells, the selectivity index (SI) of the most active fraction was determined. For in vitro studies, SI value less than 1 is classified as non-selective (toxic), between 1 and 10 is weakly selective and a SI higher than 10 is considered safe (non-toxic) [26, 27]. From the selectivity studies, DMB had a SI value of 13.7 when compared to CTX with SI of 5.4 (Table 3). This means that DMB was approximately 14 times more toxic to the cancer cell line (RD) compared to normal cells (Vero), an indication that its cytotoxic activity is selective for the cancer cell line under investigation. Similarly, ECP displayed a SI value of 11.1, suggesting that this fraction, possibly possess bioactive compounds, with high selectivity for cancer cell line. However, it is essential to evaluate the cytotoxic activity of the DMB and ECP on other cancer cell lines, to have a holistic view of their activity. 
Table 3 Antiproliferative activity of fractions of M. barteri and C. portoricensis

\begin{tabular}{|c|c|c|c|c|c|c|}
\hline \multirow[t]{2}{*}{ Plant } & \multirow[t]{2}{*}{ Fractions } & \multicolumn{2}{|c|}{$\begin{array}{l}\text { Antiproliferative activity } \\
\mathrm{CC}_{50}(\mu \mathrm{g} / \mathrm{mL})\end{array}$} & \multirow[b]{2}{*}{ PNT2 } & \multirow{2}{*}{$\begin{array}{l}\text { Selectivity Index } \\
\text { Vero }\end{array}$} & \multirow[b]{2}{*}{ PNT2 } \\
\hline & & $\mathrm{RD}$ & Vero & & & \\
\hline \multirow[t]{4}{*}{ M. barteri } & hexane & $25.6 \pm 0.21$ & $62.07 \pm 0.98$ & $88.23 \pm 2.11$ & 2.4 & 3.4 \\
\hline & DCM & $0.15 \pm 0.01$ & $2.06 \pm 0.11$ & $2.91 \pm 0.18$ & 13.7 & 19.4 \\
\hline & EtOAc & $2.98 \pm 0.09$ & $10.87 \pm 0.35$ & $17.12 \pm 0.41$ & 3.7 & 5.7 \\
\hline & aqueous & $3.06 \pm 0.11$ & $13.04 \pm 0.41$ & $18.13 \pm 1.03$ & 4.3 & 5.9 \\
\hline \multirow[t]{3}{*}{ C. portoricensis } & hexane & $2.99 \pm 0.04$ & ND & $15.11 \pm 1.02$ & - & 5.1 \\
\hline & EtOAc & $0.25 \pm 0.03$ & ND & $2.77 \pm 0.12$ & - & 11.1 \\
\hline & aqueous & $3.04 \pm 0.19$ & ND & $12.12 \pm 0.67$ & - & 4.0 \\
\hline Cyclophosphamide & CTX & $0.97 \pm 0.03$ & $5.23 \pm 0.21$ & ND & - & 5.4 \\
\hline
\end{tabular}

ND not determined, EtOAc ethyl acetate

Macaranga barteri is grown for medicinal uses and its stem is widely used as firewood in Nigeria. It is use for the management of malaria, diabetes, bronchitis and cancer in Nigeria [28, 29] and management of gonorrhoea in Sierra Leone [30]. In an ethnobotanical study conducted by our group in south west Nigeria, TMPs use the leaves of $M$. barteri, as part of herbal recipes, for the treatment of breast and skin cancer. Briefly, TMPs cook a mixture of the leaves of $M$. barteri, Hoslundia opposita, Uvaria afzelii, together with the stem bark of Uvaria chamae, Securidaca longipedunculata, in an earthen vessel containing clean water. Two cups (approximately $20 \mathrm{~mL}$ per cup) of the decoction are administered to patients three times daily for 1 month to treat the breast cancer. In addition, other traditional healers boil the leaves of Macaranga barteri, leaves of Allium cepa, leaves of Physalis angulata and the seeds of Picralima nitida in water. Two cups (approximately $20 \mathrm{~mL}$ per cup) of the decoction are taken twice daily for 2 months for the treatment of skin cancer.

The leaves of $M$. barteri displayed strong inhibition of lipid peroxidation in linoleic acid system and moderate reducing properties [31]. The anti-inflammatory activity of the methanol extract of the stem bark of the plant was also evaluated in a cell-based respiratory burst assay with macabarterin isolated as the compound responsible for the inhibition of superoxides in the cellular assay. Acteoside, 3,5-dicaffeoylquinic acid, kaempferol-7-Oglucodise and bastadin 11 were the major compounds identified in the HPLC chromatogram of DMB. Acteoside is a phenylpropanoid glycoside with anticancer, cytotoxic, anti-inflammatory and antimetastatic activities. Acteoside exhibits antiestrogenic effects on breast cancer cells and osteoblasts, without any effect on endometrial cells [32] and another study showed that acteoside inhibits human promyelocytic HL-60 leukemia cell proliferation via

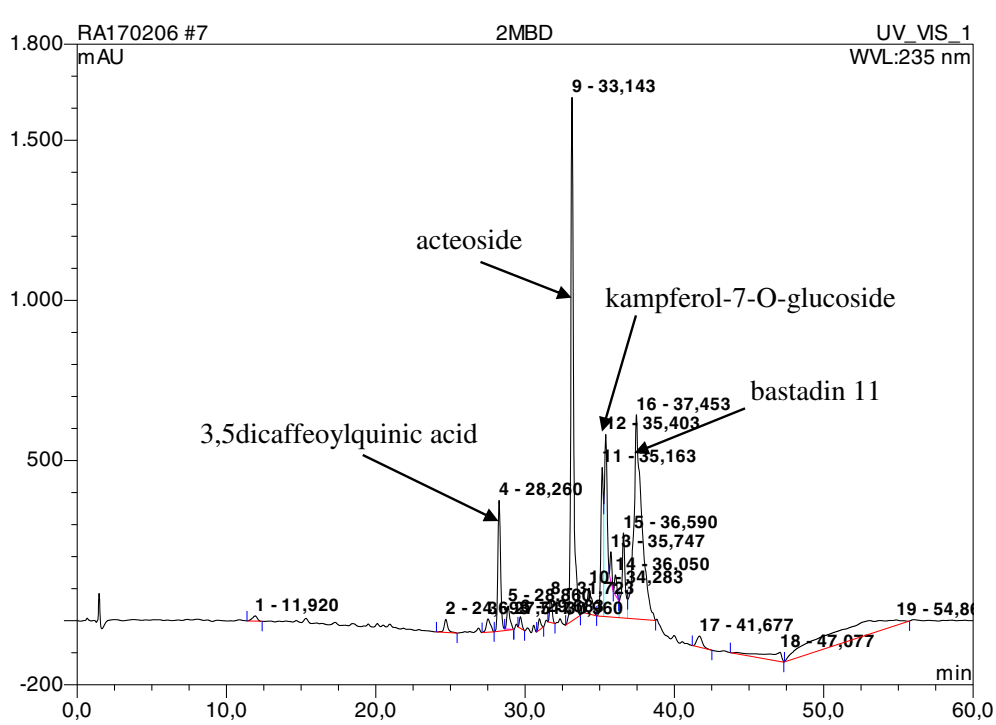

Fig. 1 Reverse Phase-HPLC Quantitative Chromatogram of the DCM fraction of Macaranga barteri leaves 

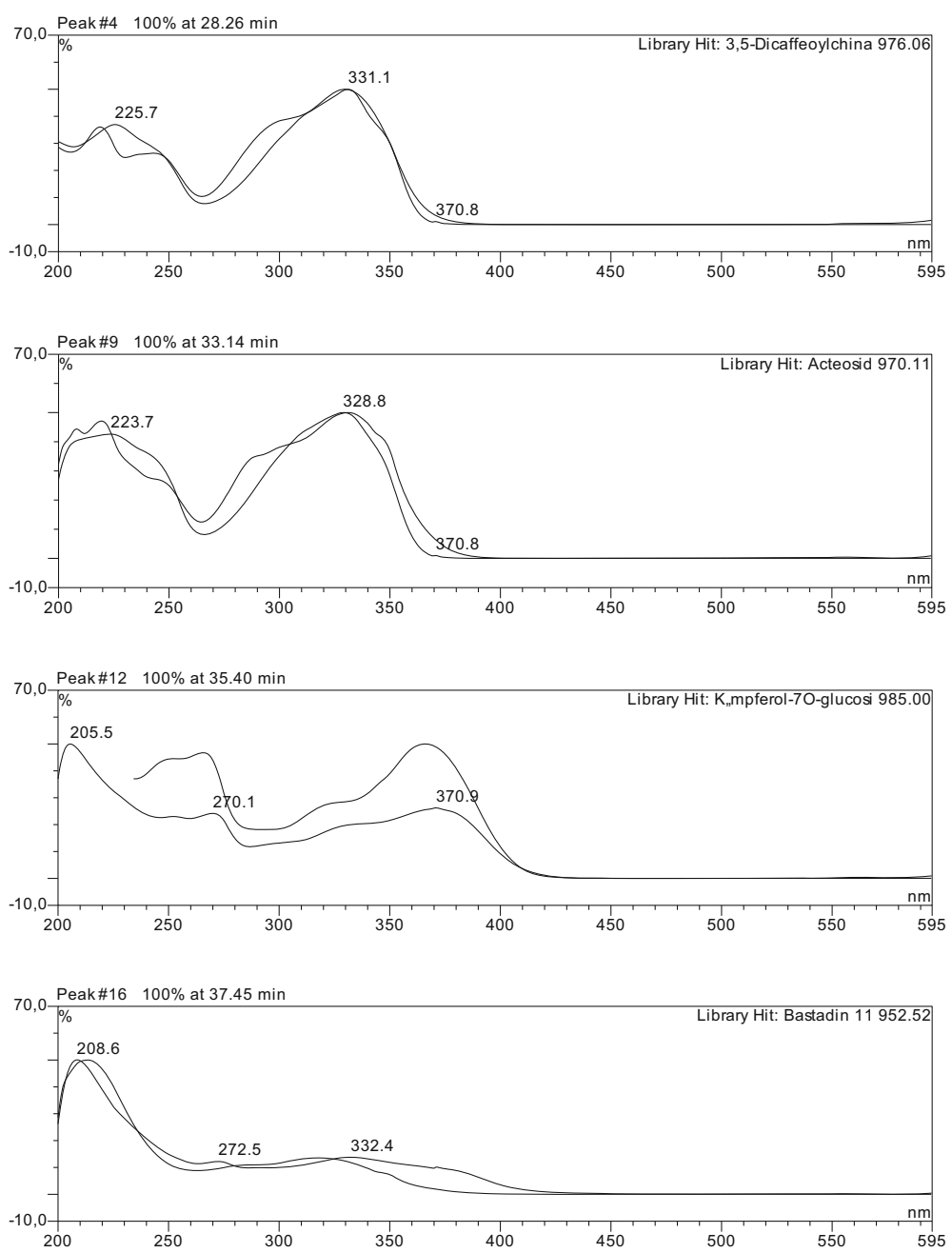

Fig. 2 UV spectra assignment of major peaks of the DCM fraction of Macaranga barteri leave

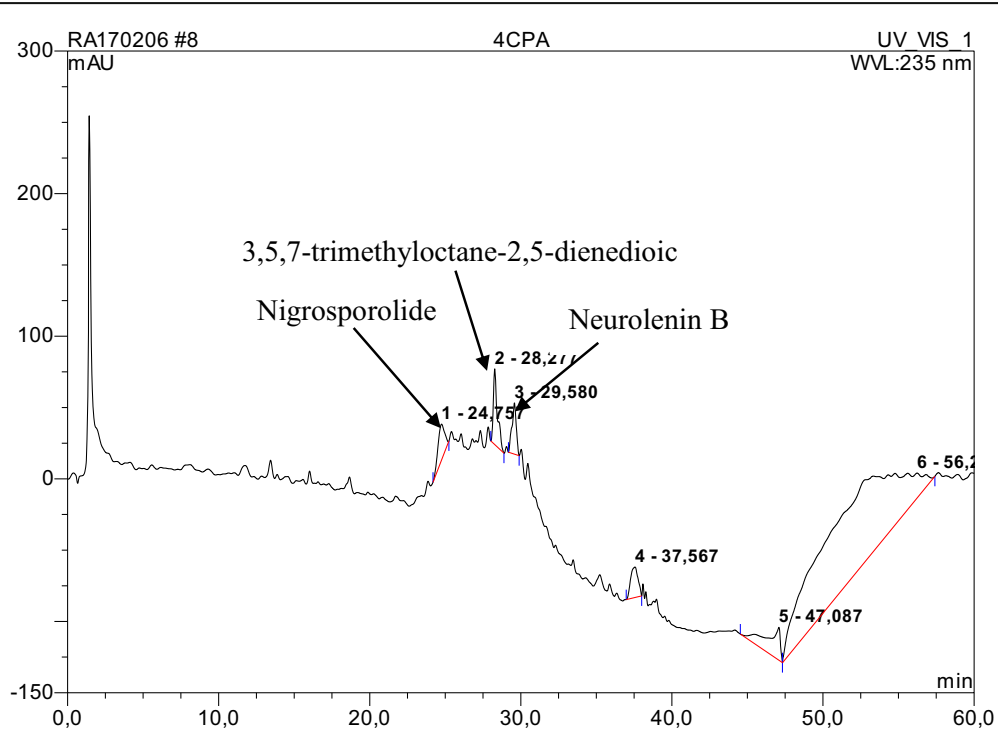

Fig. 3 Reverse Phase-HPLC Quantitative Chromatogram of ethyl acetate fraction of the root of Calliandra portoricensis 

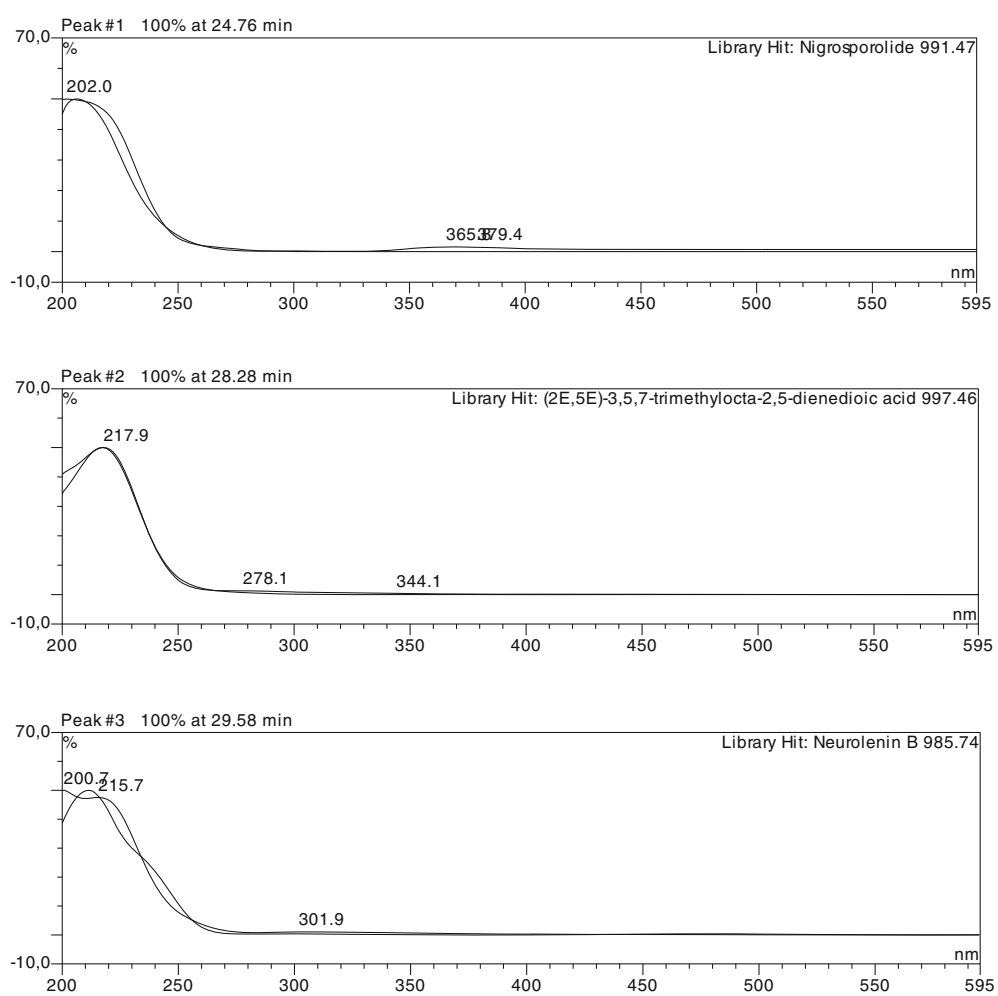

Fig. 4 UV spectra assignment of major peaks of the EtOAc fraction of Calliandra portoricensis leaves

inducing cell cycle arrest at G0/G1 phase and differentiation into monocyte [33]. Kampferol-7-O-glucoside, a flavonoid glycoside, has been reported to exhibit antimicrobial and antioxidant activities [34, 35]. Ohnishi et al. reported that 3,5-dicaffeoylquinic acid showed more scavenging activities on DPPH than $\alpha$-tocopherol or ascorbic acid [36]. Several bastadin analogues have been shown to possess in vitro cytotoxic activity against Sup-T1 cancer cells (T cell lymphoma) [37]. Other compounds present in small quantities in DMB include 3,6-Odimethylellagic acid, viridicatol, oxaline and meleagrin. Incidentally, ellagic acid and 3-O-methylellagic acid have been isolated previously from the stem bark of $M$. barteri [38]. To the best of our knowledge, this is the first report on the cytotoxicity of any extract of Macaranga barteri on any cancer cell lines.

Calliandra portoricensis is widely used in the southwestern part of Nigeria for the treatment of prostate cancer, gonorrhoea, malaria, stomach ulcers and various gastrointestinal disorders [39, 40]. In Nigeria traditional medicine, the root of C. portoricensis is used, as part of herbal recipes, for the treatment of breast and prostate cancer. For the treatment of breast cancer, the grounded root of $C$. portoricensis, Aloe vera leaves together with the unripe fruits of Carica papaya and Ananas comosus, are soaked in pap water for 7 days. Two cups (approximately $20 \mathrm{~mL}$ per cup) of the infusion is taken twice daily for 1 month. To prepare the pap water, dried corn is soaked in water for 3-4 days to make it tender, after which it is blended to a paste of fine consistency. The paste is sieved to remove any corn chaff and allowed to stand for about 3 days. The liquid on top of this corn preparation (supernatant) is referred to as pap water. For the treatment of prostate cancer, the roots of $C$. portoricensis, leaves of Andrographis paniculata, seeds of Lagenaria breviflora and the roots of Olax subscorpioides are cooked together in an earthen vessel. A cup of the decoction is taken thrice daily for 2 months.

The aqueous extracts of both root and stem of Calliandra portoricensis possess anticonvulsant activity when given intraperitoneally [40] and a recent study showed that the methanol root extract of $C$. portoricensis had significant inhibitory activity on prostate cancer cell lines PC-3 and LNCaP (androgen-refractory and androgen dependent PCa-derived cell lines) growth [41]. The HPLC analysis of ECP showed that neurolenin $\mathrm{B}$, nigrosporolide and 3,5,7-trimethyloctane-2,5-dienedioic were the main the major compounds. Neurolenin B has been reported as cytotoxic to human small lung carcinoma in vitro and having strong antimalarial activity against $P$. falciparum. Nigrosporolide, a 14-membered lactone with plant growth inhibitory activity inhibited the growth of etiolated wheat coleoptiles [42]. However, the chemical principle responsible for the cytotoxic activity is yet to be determined. 


\section{Conclusion}

This research revealed that eleven out of the 31 extracts investigated displayed significant cytotoxic activity, with extracts from two of the plant species (Macaranga barteri and Calliandra portoricensis), showing cytotoxicity higher than the positive control (cyclophosphamide). This gives credence to the ethnopharmacological approach for the selection of specific plant species for natural product biodiscovery. Also, this study showed that two fractions namely: dichloromethane fraction of Macaranga barteri (DMB) and the ethyl acetate fraction of Calliandra portoricensis (ECP) displayed significant cytotoxic activity. Dicaffeoylquinic acid, acteoside, kampferol-7-O-glucoside and bastadin 11 identified in $\mathrm{DMB}$ and neurolenin $\mathrm{B}$, nigrosporolide and 3,5,7-trimethyloctane-2,5-dienedioic identified in ECP, may be responsible for the observed cytotoxicity of the plant extracts. However, additional research to confirm this and/ or to identify novel natural products, that in fact, are the cytotoxic compounds of interest is ongoing.

\begin{abstract}
Abbreviations
BSLA: Brine shrimp lethality assay; CTX: Cyclophosphamide;

DMB: Dichloromethane fraction of Macaranga barteri;

DMSO: Dimethylsulphoxide; DPHUI: Department of Pharmacognosy

Herbarium, University of Ibadan; ECP: Ethyl acetate fraction of Calliandra portoricensis; FHI: Forest Herbarium Ibadan (FHI); HPLC: High performance liquid chromatography; LD 50 : Half-maximal lethal dose; MTT: 3-(4,5-dimethyl2-thiazolyl)-2,5-diphenyl-2-H-tetrazolium bromide, $\mathrm{CC}_{50}$ Half-maximal cytotoxic concentration; RD: Rhabdomyosarcoma; SI: Selective index; TMPs: Traditional medical practitioners; Vero: African green monkey kidney cells, PNT2Human immortalised normal prostate cells; WHO: World Health Organization
\end{abstract}

\section{Acknowledgements}

The authors sincerely appreciate the W.H.O. Polio laboratory, Department of Virology, College of Medicine, University of Ibadan, Nigeria for providing the equipment and materials for this study. We also acknowledge the staff of the Forest herbarium Ibadan (FHI) and Department of Pharmacognosy Herbarium, University of Ibadan (DPHUI) for the identification of plants.

\section{Funding}

No funding.

\section{Availability of data and materials}

All data generated or analyzed during this study are included in this article, the materials and data of our study are available to other researchers upon request.

\section{Authors' contributions}

OOO and PAS conceived and designed the experiments. PAS carried out the plant extraction. OOO, PAS and AJA performed the brine shrimp and MTT assays. AJA provided some cell culture materials. PAS prepared the manuscript and it was reviewed by 000 . All authors read and approved the final version of the manuscript.

\section{Ethics approval and consent to participate}

Not applicable in this section.

\section{Consent for publication}

Not applicable in this section.

\section{Competing interests}

The authors declare that they have no competing interests.

\section{Publisher's Note}

Springer Nature remains neutral with regard to jurisdictional claims in published maps and institutional affiliations.

\section{Author details}

'Department of Pharmacognosy, Faculty of Pharmacy, University of Ibadan, Ibadan, Nigeria. ${ }^{2}$ Department of Pharmacognosy, Faculty of Pharmacy, Olabisi Onabanjo University, Sagamu Campus, Ago-Iwoye, Nigeria. ${ }^{3}$ Department of Virology, College of Medicine, University of Ibadan, Ibadan, Nigeria.

Received: 27 June 2017 Accepted: 14 November 2017

Published online: 22 November 2017

\section{References}

1. Fitzmaurice C, Allen C, Barber RM, Barregard L, Bhutta ZA, Brenner H, Dicker DJ, Chimed-Orchir O, Dandona R, Dandona L, Fleming T. Global, regional, and national cancer incidence, mortality, years of life lost, years lived with disability, and disability-adjusted life-years for 32 cancer groups, 1990 to 2015: a systematic analysis for the global burden of disease study. JAMA Oncology. 2017;3(4):524-48.

2. Sylla BS, Wild CP. A million Africans a year dying from cancer by 2030: what can cancer research and control offer to the continent? Int J Cancer. 2012; 130(2):245-50.

3. Popoola A, Omodele F, Oludara M, Ibrahim N, Igwilo A, Makanjuola S. Prevalence and pattern of cancers among adults attending a tertiary health institution in Lagos. Nigeria IOSR-JDMS. 2013;6(3):68-73.

4. Ognjanovic S, Linabery AM, Charbonneau B, Ross JA. Trends in childhood rhabdomyosarcoma incidence and survival in the United States, 1975-2005. Cancer. 2009;115(18):4218-26.

5. Mandong BM, Ngbea JA. Childhood rhabdomyosarcoma: a review of 35 cases and literature. Niger. J. Med.J. Natl. Assoc. Resident Doct. Niger. 2011;20(4):466.

6. Newman DJ, Cragg GM. Natural products as sources of new drugs from 1981 to 2104. J Nat Prod. 2016;79:629-61.

7. Ogbourne SM, Parsons PG. The value of nature's natural product library for the discovery of new chemical entities: the discovery of ingenol mebutate. Fitoterapia. 2014;98:36-44.

8. Noble RL. The discovery of the vinca alkaloids - chemotherapeutic agents against cancer. Biochem Cell Biol. 1990;68(12):1344-51.

9. Wall ME, Wani MC. Camptothecin and taxol: from discovery to clinic. J Ethnopharmacol. 1996;51(1):239-54.

10. WHO. WHO traditional medicine strategy 2002-2005. 2002.

11. Gbile Z, Adesina S. Nigerian flora and its pharmaceutical potential. J Ethnopharmacol. 1987;19(1):1-16.

12. Ajaiyeoba E, Ashidi J, Abiodun O, Okpako L, Ogbole O, Akinboye D, Falade C, Bolaji O, Gbotosho G, Falade M. Antimalarial ethnobotany: in vitro. Antiplasmodial activity of seven plants identified in the Nigerian middle belt. Pharm Biol. 2005;42(8):588-91.

13. Abubakar M, Musa A, Ahmed A, Hussaini I. The perception and practice of traditional medicine in the treatment of cancers and inflammations by the Hausa and Fulani tribes of northern Nigeria. J Ethnopharmacol. 2007;111(3):625-9.

14. Soladoye MO, Amusa N, Raji-Esan S, Chukwuma E, Taiwo A. Ethnobotanical survey of anti-cancer plants in Ogun state, Nigeria. Annals. Biol Res. 2010; 1(4):261-73.

15. Ngulde SI, Sandabe UK, Hussaini IM. Ethnobotanical survey of anticancer plants in Askira/Uba local government area of Borno state, Nigeria. Afr J Pharm Pharmacol. 2015;9(5):123-30.

16. Ogbole OO, Adeniji JA, Ajaiyeoba EO. Cytotoxicity evaluation of sixteen Nigerian medicinal plant extracts using the human rhabdomyosarcoma cell line. Niger J Nat Prod Med. 2015;18(1):1-6.

17. Ashidi JS, Houghton PJ, Hylands PJ, Efferth T. Ethnobotanical survey and cytotoxicity testing of plants of South-western Nigeria used to treat cancer, with isolation of cytotoxic constituents from Cajanus cajan Millsp. Leaves. J Ethnopharmacol. 2010;128(2):501-12.

18. Mclaughlin JL. Crown gall tumours on potato discs and brine shrimp lethality: two simple bioassays for higher plant screening and fractionation. Methods in plant. Biochemistry. 1991;6:1-32.

19. Mosmann T. Rapid colorimetric assay for cellular growth and survival: application to proliferation and cytotoxicity assays. J Immunol Methods. 1983;65(1-2):55-63.

20. Meyer B, Ferrigni N, Putnam J, Jacobsen L, Nichols DJ, McLaughlin JL. Brine shrimp: a convenient general bioassay for active plant constituents. Planta Med. 1982:45(05):31-4.

21. Ramachandran S, Vamsikrishna M, Gowthami K, Heera B, Dhanaraju M. Assessment of cytotoxic activity of Agave cantula using brine shrimp (Artemia salina) lethality bioassay. Asian J, Sci. Res. 2011;4(1):90-4. 
22. Riss TL, Moravec RA, Niles AL, Duellman S, Benink HA, Worzella TJ, Minor L. Cell viability assays. 2016

23. Gerlier D, Thomasset N. Use of MTT colorimetric assay to measure cell activation. J Immunol Methods. 1986;94(1-2):57-63.

24. Suffness M, Pezzuto JM. Assays related to cancer drug discovery. Methods in Plant Biochemistry: Assays for Bioactivity. 1990;6:71-133.

25. Wong YH, Abdul Kadir H, Ling SK: Bioassay-Guided Isolation of Cytotoxic Cycloartane Triterpenoid Glycosides from the Traditionally Used Medicinal Plant Leea indica. Evidence-based complementary and alternative medicine: eCAM. 2012;2012:164689.

26. Ondo J, Lekana-Douki J, Bongui J, Zang Edou E, Zatra R, Toure-Ndouo F, Elomri A, Lebibi J, Seguin E. Vitro antiplasmodial activity and cytotoxicity of extracts and fractions of Vitex madiensis, medicinal plant of Gabon. Tropical Med Int Health. 2012;17(3):316-21.

27. Ogbole OO, Ajaiyeoba EO, Adeniji JA, Kamdem SR, Sajan S, Muhammad IC Bioassay-guided isolation of poliovirus-inhibiting constituents from Zephyranthes candida. Pharm Biol. 2015;53(6):882-7.

28. Gbadamosi IT, Erinoso SMA. Review of twenty ethnobotanicals used in the management of breast cancer in Abeokuta, Ogun state, Nigeria. Afr J Pharm Pharmacol. 2016;10(27):546-64.

29. Soladoye M, Chukwuma E, Owa F. An 'Avalanche'of plant species for the traditional cure of diabetes mellitus in south-western Nigeria. J Nat Prod Plant Resour. 2012;2(1):60-72.

30. Oliver-Bever B: Medicinal plants in tropical West Africa: Cambridge University press; 1986.

31. Adesegun S, Elechi N, Coker H. Antioxidant power of Macaranga barteri leaf. Am j Food Tech. 2007;2:543-9.

32. Lee S-Y, Lee K-S, Yi SH, Kook S-H, Lee J-C. Acteoside suppresses RANKLmediated Osteoclastogenesis by inhibiting c-Fos induction and NF-KB pathway and attenuating ROS production. PLoS One. 2013;8(12):e80873.

33. Lee K-W, Kim HJ, Lee YS, Park H-J, Choi J-W, Ha J, Lee K-T. Acteoside inhibits human promyelocytic HL-60 leukemia cell proliferation via inducing cell cycle arrest at G 0 /G 1 phase and differentiation into monocyte. Carcinogenesis. 2007;28(9):1928-36.

34. Singh D, Sharma S, Rani R, Mishra S, Sharma R. Kaempferol-7-O-Glucoside and their antimicrobial screening isolate from Cassia renigera wall. Int. J. Pharm. Clin Res. 2011:3(2):30-4.

35. Süzgeç-Selçuk S, Birteksöz AS. Flavonoids of Helichrysum chasmolycicum and its antioxidant and antimicrobial activities. S Afr J Bot. 2011;77(1):170-4.

36. Ohnishi M, Morishita H, Iwahashi H, Toda S, Shirataki Y, Kimura M, Kido R. Inhibitory effects of chlorogenic acids on linoleic acid peroxidation and haemolysis. Phytochemistry. 1994;36(3):579-83.

37. Reddy AV, Ravinder K, Narasimhulu M, Sridevi A, Satyanarayana N, Kondapi AK, Venkateswarlu Y. New anticancer bastadin alkaloids from the sponge Dendrilla cactos. Bioorg Med Chem. 2006;14(13):4452-7.

38. Ngoumfo RM, Ngounou GE, Tchamadeu CV, Qadir MI, Mbazoa CD, Begum A, Ngninzeko FN, Lontsi D, Choudhary MI. Inhibitory effect of Macabarterin, a Polyoxygenated Ellagitannin from Macaranga barteri, on human Neutrophil respiratory burst activity. J Nat Prod. 2008;71(11):1906-10.

39. Burkill HM: The useful plants of west tropical Africa, Vols. 1-3: Royal Botanic Gardens, Kew; 1995.

40. Akah PA, Nwaiwu Jl. Anticonvulsant activity of root and stem extracts of Calliandra portoricensis. J Ethnopharmacol. 1988;22(2):205-10.

41. Adaramoye O, Erguen B, Oyebode O, Nitzsche B, Höpfner M, Jung K, Rabien A. Antioxidant, antiangiogenic and antiproliferative activities of root methanol extract of Calliandra portoricensis in human prostate cancer cells. J. Integr Med. 2015;13(3):185-93.

42. Harwooda JS, Cutler HG, Jacyno JM. Nigrosporolide, a plant growthinhibiting macrolide from the mould Nigrospora sphaerica. Nat Prod Lett. 1995;6(3):181-5.

\section{Submit your next manuscript to BioMed Central and we will help you at every step:}

- We accept pre-submission inquiries

- Our selector tool helps you to find the most relevant journal

- We provide round the clock customer support

- Convenient online submission

- Thorough peer review

- Inclusion in PubMed and all major indexing services

- Maximum visibility for your research

Submit your manuscript at www.biomedcentral.com/submit
Biomed Central 